\title{
OPTIMASI FORMULASI BREAKFAST MEAL FLAKES (PANGAN SARAPAN) PISANG DENGAN PENAMBAHAN LABU KUNING
}

\section{OPTIMIZE FORMULATION THE BREAKFAST MEAL FLAKES (FOOD BREAKFAST) BANANAS WITH THE ADDITION OF PUMPKINS}

\author{
Kurnia Rimadhanti Ningtyas ${ }^{1 *}$ \\ ${ }^{1}$ Program Studi Teknologi Pangan, Jurusan Teknologi Pertanian Politeknik Negeri Lampung, Indonesia
}

\begin{abstract}
ABSTRAK
Flakes atau sereal merupakan makanan sarapan yang banyak digemari masyarakat, karena flakes mudah untuk digunakan. Flakes umumnya dibuat dari bahan baku yang berasal dari golongan serealia dan umbi-umbian, seperti tepung terigu dan tapioka yang merupakan sumber karbohidrat dengan gula, garam dan air (Marsetio, 2006). Inovasi telah dilakukan dalam pengolahan flakes untuk meningkatkan nilai nutrisi dari flakes tersebut. Tujuan dari penelitian ini adalah menentukan formulasi tepung pisang dan labu kuning yang optimal terhadap tekstur flakes berdasarkan tingkat kesukaan konsumen. Penelitian ini akan dilakukan dengan tiga ulangan dan terdiri dari perbandingan tepung pisang dan tepung labu kuning, yaitu: $\mathrm{P} 1=$ tepung pisang $70 \%$ : tepung labu kuning $0 \%$ : tepung terigu $30 \% ; \mathrm{P} 2=$ tepung pisang $60 \%$ : tepung labu kuning $10 \%$ : tepung terigu $30 \%$; P3 = tepung pisang $50 \%$ : tepung labu kuning $20 \%$ : tepung terigu $30 \%$; $\mathrm{P} 4=$ tepung pisang $40 \%$ : tepung labu kuning $30 \%$ : tepung terigu $30 \%$; $\mathrm{P} 5=$ tepung pisang $30 \%$ : tepung labu kuning $40 \%$. : tepung terigu 30\%. Dari hasil pengamatan dan pembahasan dapat disimpulkan bahwa formulasi tepung pisang dan tepung labu kuning dalam pembuatan flakes yang paling disukai oleh konsumen adalah dengan perbandingan tepung pisang $60 \%$, tepung labu kuning $10 \%$ dan tepung terigu $30 \%$.
\end{abstract}

Katakunci: Flakes, tepung pisang, tepung labu kuning

\begin{abstract}
Flakes or cereal is a breakfast food many popular the community, because flakes easy to used. Flakes generally made from raw materials from the cereal and roots, such as wheat flour and tapioca that is a source of carbohydrates with sugar, salt and water (Marsetio, 2006). Innovation carried out in flakes processing to increase the value nutrients from the flakes. The purpose of this research is to determine the banana flour and yellow squash formulations optimal against texture flakes based on consumer fondness. This research will be carried out through three preparation of test questions and consisting from a comparison of the banana flour and pumpkin flour, is $P 1=$ banana fluor $70 \%$ : pumpkin flour 0\%: wheat flour $30 \%$; P2 = banana fluor 60\% : pumpkin flour 10\% : wheat flour 30\%; P3 = banana fluor 50\% : pumpkin flour 20\%: wheat flour 30\%; P4 = banana fluor 40\% : pumpkin flour $30 \%$ : wheat flour 30\%; P5 = banana fluor 30\% : pumpkin flour 40\%. : wheat flour 30\%. The result of observation and discussion it can be concluded that formulations the banana flour and pumpkin flour in the manufacture of flakes most favored by consumers is by comparison the banana flour $60 \%$, pimpkin flour $10 \%$ and wheat flour $30 \%$.
\end{abstract}

Keywords: Flakes, Banana flour, pumpkin flour

\section{Pendahuluan}

Flakes atau sereal merupakan makanan sarapan yang banyak digemari masyarakat, karena mudah untuk dikonsumsi. Flakes

\footnotetext{
${ }^{*}$ Penulis Korespondensi.

E-mail: ningtiyas@ polinelas.ac.id
}

merupakan makanan sereal setiap santap yang umumnya dikonsumsi dengan susu. Flakes umumnya dibuat dari bahan baku yang berasal dari golongan serealia dan umbi-umbian, seperti tepung terigu dan tapioka yang merupakan sumber karbohidrat dengan penambahan gula, garam dan air (Marsetio, 2006). Flakes biasanya dibuat dari biji jagung yang utuh yang dikenal 
dengan nama corn flakes. Flakes digolongkan kedalam jenis makanan sereal siap santap yang telah dan direkayasa menurut jenis dan bentuknya dan merupakan makanan siap saji yang praktis (Anggara dkk, 2011). Saat ini telah dikembangkan inovasi dalam pengolahan flakes.

Inovasi dalam pengolahan flakes dilakukan untuk meningkatkan nilai nutrisi dari flakes tersebut. Beberapa penelitian dalam pembuatan flakes telah dilakukan seperti dalam penelitian Rahayuning (2004) yang menentukan formulasi flakes berbahan baku tepung ubi jalar, kecambah kedelai, wheat germ sebagai produk sarapan fungsional untuk anak-anak, juga penelitian dari Suarni (2009) yang membuat makanan ringan (flakes) berbasis jagung dan kacang hijau sebagai sumber protein untuk perbaikan gizi anak usia tumbuh.

Pisang merupakan bahan pangan yang banyak mengandung karbohidrat, vitamin, dan mineral yang diperlukan oleh tubuh. Pemanfaatan buah pisang (Musa parasidisiaca), selama ini belum optimal masih terbatas buah konsumsi segar dan olahan tradisional. Pisang mentah tua, berpotensial sebagai sumber karbohidrat dan berpeluang untuk dikembangkan terutama sebagai bahan pembuatan tepung dan produk olahannya. Salah satu alternatif bentuk pengolahan pangan yang dapat meningkatkan penerimaan dan keawetan pisang dan praktis penyajian, yaitu dengan diolah menjadi flakes pisang.

Labu kuning memiliki kandungan zat gizi yang sangat banyak seperti protein yaitu sebesar 1,1gram/100gram bahan dan pro vitamin A atau $\beta$-karoten sebesar 180SI/100gram bahan (Depkes RI, 1996), sehingga labu kuning dapat dimanfaatkan menjadi salah satu sumber vitamin A yang sangat diperlukan oleh tubuh. Labu kuning dapat dilakukan inovasi dengan pembuatan tepung labu kuning. Tepung labu kuning dapat digunakan sebagai bahan pensubstitusi tepung terigu. Pemanfaatan labu kuning dengan menjadikan tepung adalah untuk menambah masa simpan labu kuning. Beberapa produk yang dapat disubstitusikan dengan tepung labu kuning antara lain mie, biskuit, roti tawar dan cake (Yuliani, 2005).

Tujuan dari penelitian ini adalah menentukan formulasi tepung pisang dan labu kuning yang optimal terhadap tekstur flakes berdasarkan tingkat kesukaan konsumen. Penelitian ini diharapkan dapat memberikan infirmasi inovasi sereal sarapan atau flakes yang tidak hanya dimiliki kadar karbohidrat yang tinggi tetapi juga memiliki serat dan vitamin A yang baik.

\section{Metode Penelitian}

\section{Waktu dan Tempat}

Penelitian ini dilaksanakan di Laboratorium Teknologi Hasil Pertanian Politeknik Negeri Lampung, pada tahun 20162017.

\section{Desain Penelitian}

Penelitian ini akan dilakukan dengan tiga ulangan dan terdiri dari perbandingan tepung pisang dan tepung labu kuning, yaitu:

$\mathrm{P} 1=$ tepung pisang $70 \%$ : tepung labu kuning $0 \%$ : tepung terigu $30 \%$

$\mathrm{P} 2=$ tepung pisang $60 \%$ : tepung labu kuning $10 \%$ : tepung terigu $30 \%$

P3 = tepung pisang 50\% : tepung labu kuning $20 \%$ : tepung terigu $30 \%$

$\mathrm{P} 4=$ tepung pisang $40 \%$ : tepung labu kuning $30 \%$ : tepung terigu $30 \%$

P5 = tepung pisang 30\% : tepung labu kuning $40 \%$. : tepung terigu $30 \%$

\section{Tahapan Penelitian}

Penelitian dilakukan dengan dua tahap, yaitu penelitian pendahuluan dan penelitian lanjutan. Penelitian pendahuluan meliputi proses pembuatan tepung pisang dan tepung labu kuning, sedangkan tahap lanjutan yaitu pembuatan flakes dengan berbagai macam proporsi penambahan tepung pisang, tepung labu kuning, dan tepung terigu.

Proses pembuatan tepung pisang pada penelitian pendahuluan dilakukan dengan memilih pisang yang sudah tua dan masih mentah. kemudian mengupas buah pisang hingga bersih. Daging buah yang didapat diiris tipis, lalu dilakukan perendaman dengan larutan garam 5\% selama \pm 10 menit, perendaman ini dimaksudkan untuk mengurangi browning/pencoklatan yang terjadi pada daging buah pisang. Kemudian daging buah pisang dilakukan pengeringan, pengeringan dapat dilakukan dengan penjemuran dibawah sinar matahari langsung atau dengan pengovenan dengan suhu $\pm 70^{\circ} \mathrm{C}$ selama \pm 48 jam. Pisang yang sudah kering dan siap dihaluskan ditandai dengan mudah dipatahkan. Potongan pisang yang sudah kering dilakukan pengecilan ukuran dengan penggilingan kemudian mengayak dengan ayakan 80 mesh. Proses pembuatan tepung pisang dapat dilihat pada Gambar 1. 


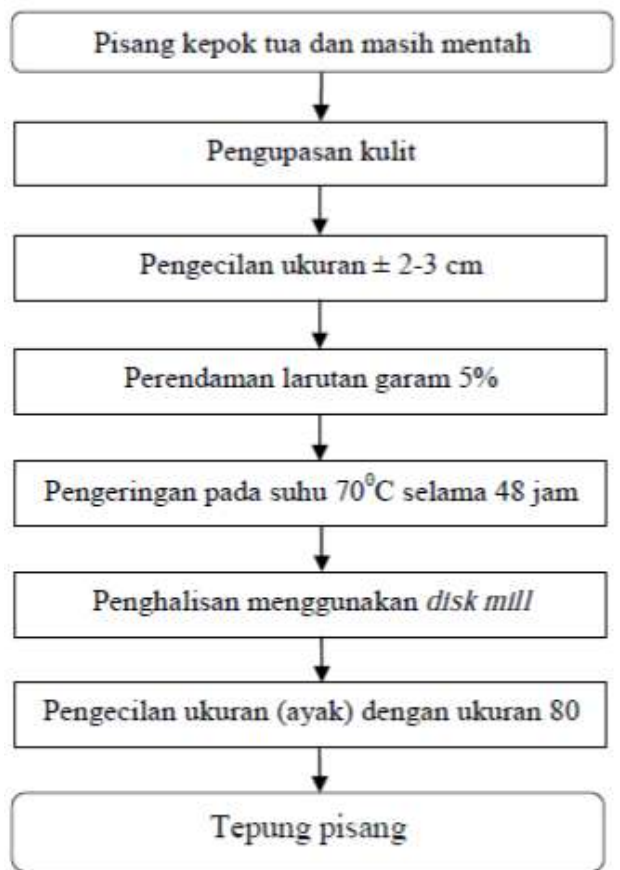

Gambar 1. Proses Pembuatan tepung pisang Sumber : Papunas, (dimodifikasi)

Proses pembuatan tepung labu kuning diawali dengan memilih labu kuning yang tua dan mentah. Mengupas labu kuning dan, membuang bagian kulit, jaring-jaring dan bijinya. kemudian mengiris dengan ketebalan 1-2 mm. Irisan labu kuning dikeringkan dengan pengering kabinet dengan suhu $70^{\circ} \mathrm{C}$ selama 36 jam. Kemudian dihancurkan dengan menggunakan blender hingga halus dan kemudian diayak dengan ayakan 80 mesh. Diagram alir proses pembuatan tepung labu kuning dapat dilihat pada Gambar 2.

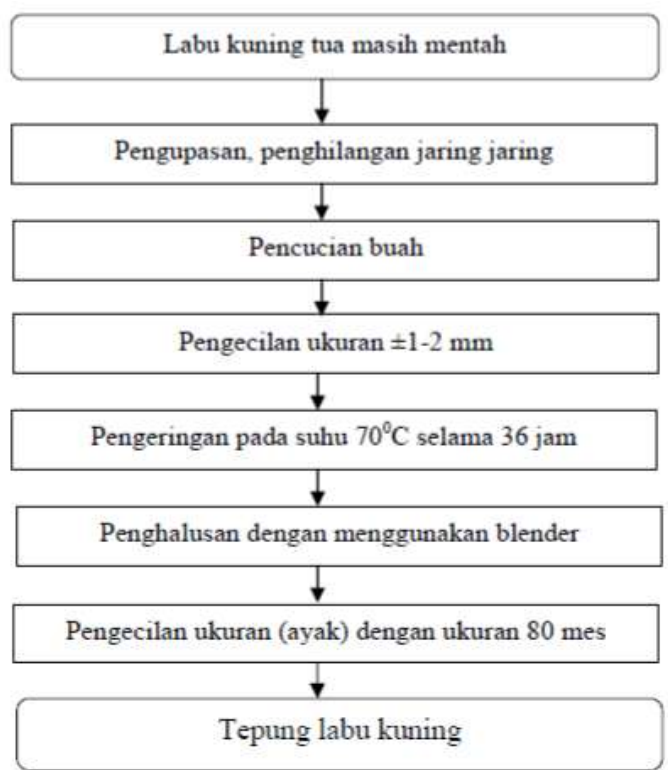

Gambar 2. Proses pembuatan tepung labu kuning Sumber: Purnamasari, 2015
Proses pembuatan flakes pisang labu kuning dilakukan sebagai berikut. Tepung pisang, tepung labu kuning, dan tepung terigu ditimbang dengan perbandingan $\mathrm{P} 1=70 \%: 0 \%: 30 \% ; \mathrm{P} 2=$ 60\%:10\%:30\%; P3 = 50\%:20\%:30\%; P4 = 40\%:30\%:30\%, dan P5 = 30\%:40\%:30\%, kemudian ditambahkan margarin $1 / 4$ bagian, gula halus $10 \%$, garam $1 \%$, susu bubuk $10 \%$ dan air \pm $15 \%$ dari berat total bahan.Campuran tersebut diuleni sampai homogen menggunakan mixer dengan kecepatan 1 selama 10 menit. Adonan kemudian ditimbang dan dibagi menjadi dua untuk kemudian dipipihkan lalu dikukus selama 10 menit untuk proses pre-gelatinisasi pati agar adonan tidak pecah dan mempermudah saat proses pembentukan flakes.Adonan lalu dipipihkan dengan menggunakan noodle maker dengan skala 3 dan ketebalan $\pm 1 \mathrm{~mm}$.Adonan dilakukan pencetakan dengan ukuran $2 \times 2 \mathrm{~cm}$, lalu ditata diatas loyang dan dipanggang dengan suhu $120^{\circ} \mathrm{C}$ selama 20 menit (Purnamasari, 2015 dimodifikasi). Diagram alir proses pembuatan flakes pisang labu kuning dapat dilihat pada Gambar 3.

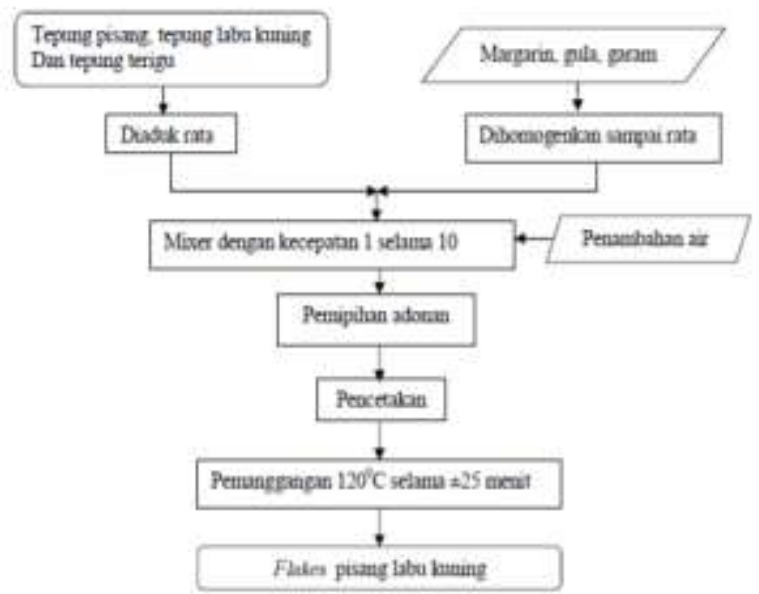

Gambar 3. Proses pembuatan flakes pisang labu kuning Sumber: Purnamasari, 2015 (dimodifikasi)

Pengamatan dan analisis yang akan dilakukan pada penelitian ini meliputi Pengujian organoleptik, dan pengujian kimia. Pengujian organoleptik meliputi warna, aroma, rasa, tekstur dan kenampakan keseluruhan yang dilakukan secara mutu hedonik, dengan menggunakan 30 oang panelis. Pengujian kimia meliputi uji kadar air dan serat kasar.

\section{Hasil Dan Pembahasan}

Flakes merupakan makanan sereal siap santap yang umumnya dikonsumsi dengan susu. Flakes merupakan bentuk pertama dari produk 
sereal siap santap. Secara tradisional, pembuatan produk flakes dilakukan dengan mengukus biji serealia yang sudah dihancurkan (kurang lebih sepertiga dari ukuran awal biji) pada kondisi bertekanan selama dua jam atau lebih lalu dipipihkan di antara dua rol baja. Setelah itu dikeringkan dan di panggang pada suhu tinggi (Tribelhorn, 1991).

Penelitian utama yang dilakukan adalah pembuatan flakes pisang labu kuning. Flakes yang dibuat dengan menggunakan 5 formulasi tepung pisang, tepung labu kuning, dan tepung terigu, yaitu sebagai berikut P1 $=70 \%: 0 \%: 30 \%$; $\mathrm{P} 2=60 \%: 10 \%: 30 \% ; \mathrm{P} 3=50 \%: 20 \%: 30 \% ; \mathrm{P} 4=$ 40\%:30\%:30\%; dan P5 = 30\%:40\%:30\%. Bahan utama yang digunakan yaitu tepung pisang kepok dan tepung labu kuning. Sedangkan bahan tambahan yang digunakan dalam pembuatan flakesantara lain tepung terigu, susu bubuk, gula pasir, lemak, baking powder, air, dan vanili.

\section{Pengujian Organoleptik}

Pengujian organoleptik dilakukan untuk mengetahui penerinaan konsumen terhadap produk flakes pisang labu kuning yang dibuat. Pengujian organoleptik dilakukan sebanyak 3 kali pengulangan. Pengamatan yang dilakukan yaitu, warna, aroma, tekstur, rasa, dan keseluruhan. Uji organoleptik yang digunakan metode uji mutu hedonik menggunakan 30 panelis.

\section{Warna}

Warna merupakan salah satu parameter yang penting dalam penilaian suatu produk.Sebagian besar konsumen lebih memilih produk yang memiliki warna yang mencolok. Pengujian organoleptik terhadap warna pada pembuatan flakes bertujuan untuk mengetahui seberapa besar pengaruh penambahan tepung labu kuning dan tepung pisang kepok terhadap warna yang dihasilkan.Hasil pengujian organoleptik terhadap kesukaan warna flakes pisang labu kuning dapat dilihat pada Gambar 4.

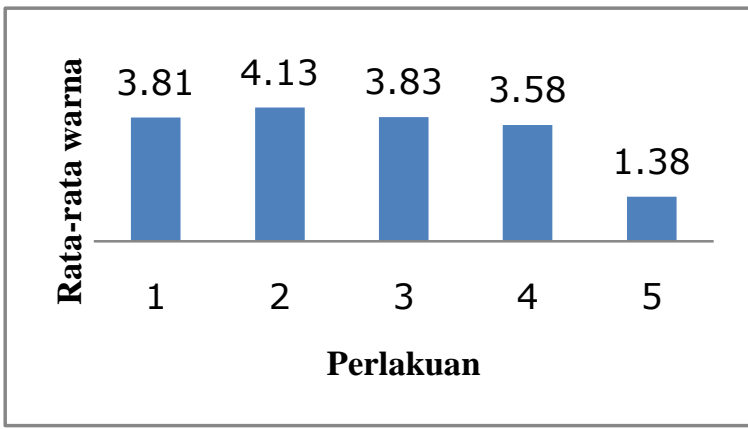

Gambar 4. Rata-rata warna flakes pisang labu kuning
Perlakuan konsentrasi tepung pisang kepok dan tepung labu sangat berpengaruh terhadap warna. Semakin banyak konsentrasi tepung labu yang diaplikasikan, maka semakin kuning dan gelap warna yang dihasilkan pada flakes. Hal ini dikarenakan labu kuning memiliki pigmen karotenoid yang tinggi dan sebagian besar berbentuk $\beta$-karoten yang merupakan provitamin A. Tingginya konsentrasi $\beta$-karoten dan karbohidrat yang dimiliki oleh labu kuning menyebabkan terjadinya browningnon enzimatis pada flakes saat dilakukan pemanggangan. Hal ini mengakibatkan semakin tinggi konsentrasi tepung labu kuning yang digunakan, semakin rendah pula penerimaan konsumen. Pada Gambar 2 dapat dilihat bahwa Perlakuan 2 merupakanpenerimaan konsumen tertinggi terhadap warna flakes pisang labu kuning dengan konsentrasi tepung labu kuning $10 \%$, tepung pisang kepok 60\%,dan tepung terigu $30 \%$. Sedangkan pada perlakuan 5 merupakan penerimaan terendah terhadap warna flakes pisang labu kuning dengan konsentrasi labu kuning tertinggi yaitu $40 \%$, tepung pisang kapok $30 \%$, dan tepung terigu $30 \%$

\section{Tekstur}

Tekstur adalah salah satu sifat bahan atau produk yang dapat dirasakan melalui sentuhan kulit ataupun pencicipan. Beberapa sifat tekstur dapat juga diperkirakan dengan menggunakan sebelah mata (berkedip) seperti kehalusan atau kekerasan dari permukaan bahan atau kekentalan cairan. Sedangkan dengan suara/bunyi dapat diperkirakan tekstur dari kerupuk (crisp food). Tekstur pada flakes sangat mempengaruhi penilaian konsumen terhadap suatu produk sereal sarapan. Hasil pengujian organoleptik tekstur flkes dapat dilihat pada Gambar 5.

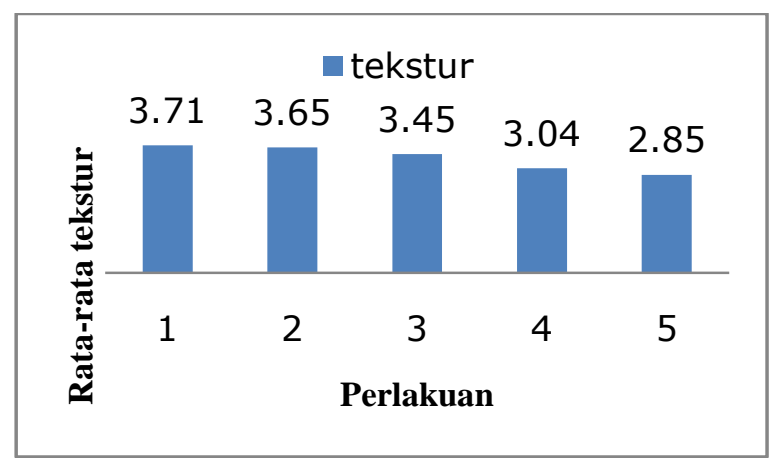

Gambar 5. Rata-rata tekstur flakes pisang labu kuning

Tekstur pada flakes berpengaruh pada tingkat kesukaan konsumen. Parameter tekstur yang digunakan yaitu tingkat kerenyahan. Karena 
pada dasarnya flakes memiliki tekstur yang renyah dan rapuh. Tetapi bila cara memakannya dengan menggunakan susu, tidak akan hancur seperti bubur karena flakes tersebut akan menyerap air yang ada disekitarnya. Pada Gambar diatas dapat dilihat bahwa, perbandingan konsentrasi tepung pisang, tepung labu kuning, dan tepung terigu sangat perpegaruh terhadap tekstur flakes yang dihasilkan.

Pada Gambar 3 dapat dilihat bahwa perlakuan 1 merupakan flakes yang memiliki tingkat kerenyahan tertinggi yaitu konsentrasi tepung labu kuning 0\%, tepung pisang kapok $70 \%$, tepung terigu $30 \%$. Semakin tinggi konsentrasi tepung labu kuning maka tingkat kerenyahan dari flakes semakin menurun. Cahyaningtyas, 2014 menyatakan bahwa penurunan tekstur pada flakes pisang labu kuning disebabkan karena kadar gluten yang berkurang serta kemampuan gelatinisasi menurun. Selain itu kadar protein pada tepung labu kuning rendah sehingga kemampuan mengikat air meningkat, dan mengakibatkan kadar air pada bahan bertambah.

\section{Rasa}

Rasa merupakan salah satu parameter yang sangat berpengaruh terhadap tingkat kesukaan konsumen.Hasil uji organoleptik flakes pisang labu kuning dapat dilihat pada Gambar 6.

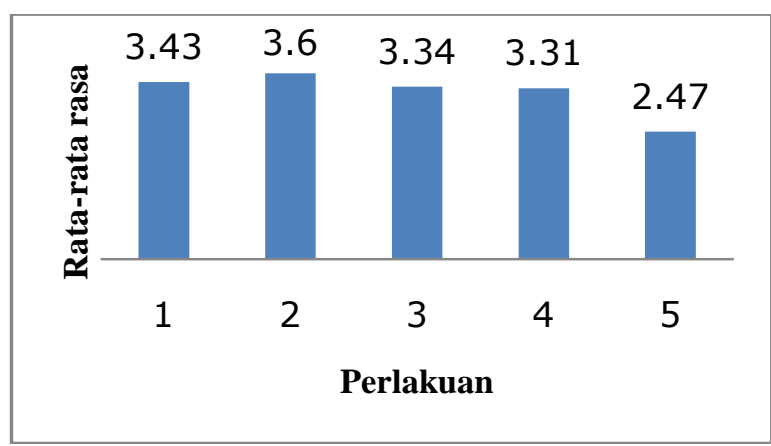

Gambar 6. Rata-rata rasa flakes pisang labu kuning.

Berdasarkan hasil uji organoleptik, flakes pisang yang paling disukai berdasarkan parameter rasa yaitu pada perlakuan 1 dengan konsentrasi tepung labu kuning $10 \%$, tepung pisang $60 \%$, dan tepung terigu $30 \%$. Dari gambar diatas dapat dilihat bahwa semakin tinggi konsentrasi tepung labu kuning, maka semakin rendah penerimaan konsumen terhadap rasa dari flakes pisang labu kuning. Menurut Cahyaningtyas, 2014 penurunan penerimaan konsumen terhadap rasa dari flakes pisang labu kuning disebabkan karena Rasa khas dari labu kuning yangsangat kuat. Rasa khas tersebut berasal darikandungan senyawa flavonoid yang terdapat padalabu kuning.

\section{Aroma}

Aroma adalah reaksi dari makanan yang akan mempengaruhi konsumen sebelum konsumen menikmati makanan, konsumen dapat mencium makanan tersebut.Hasil uji organoleptik parameter rasa flakes pisang labu kuning dapat dilihat pada Gambar 7.

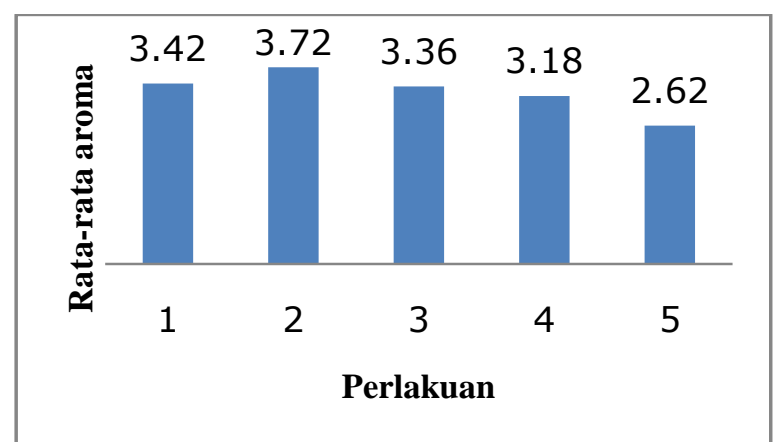

Gambar 7. Rata-rata aroma flakes pisang labu kuning

Flakes pisang yang paling disukai berdasarkan parameter aroma yaitu pada perlakuan 1 dengan konsentrasi tepung labu kuning $10 \%$, tepung pisang $60 \%$, dan tepung terigu $30 \%$. Dari gambar diatas dapat dilihat bahwa semakin tinggi konsentrasi tepung labu kuning, maka semakin rendah penerimaan konsumen terhadap aroma dari flakes pisang labu kuning.

Konsentrasi tepung labu kuning yang agak banyak menimbulkan aroma yang langu dan tidak disukai konsumen.Aroma langu yang dihasilkan pada labu kuning karena adanya senyawa kimia pada labu kuning yaitu flavanoid. Pada eggroll dengan konsentrasi $75 \%$ dan $100 \%$ diduga mengeluarkan senyawa aromatik yang terlalu kuat sehingga panelis kurang menyukai. Senyawa aromatik pada labu kuning menurut Berger (2007) terdapat komponen aliphatic alkohol dan senyawa karbonil, hexenal, 2hexenal. 3-hexen dan 2,3 butanodiene teridentifikasi pada aroma labu kuning.

\section{Keseluruhan}

Uji sensoris dengan parameter keseluruhanmerupakan penilaian konsumen terhadap semuaatribut sensoris. Penilaian atribut sensoris digunakanuntuk mengetahui tingkat penerimaan panelisterhadap produk secara keseluruhan. Penilaianparameter keseluruhan diperoleh hasil bahwa paneliscenderung lebih 
menyukaiflakes dengan konsentrasi tepung labu kuning $10 \%$, tepung pisang $60 \%$, dan tepung terigu $30 \%$.

\section{Pengujian Kimia}

Pengujiankandungan kimiayangpada flakes pisang labu kuning meliputi kadar air dan kadar serat kasar. Pengujian kadar air dan kadar serat kasar dilakukan menggunakan metode gravimetri.

\section{Kadar air}

Kadar air merupakan salah satu parameter yang sangat penting pada makanan kering. Pengujian kadar air dilakukan pada formulasi konsentrasi tepung pisang $60 \%$, tepung labu kuning $10 \%$, dan tepung terigu $30 \%$ yang merupakan formulasi paling disukai oleh konsumen. Kadar air yang didapatkan yaitu sebesar 5,65\%. Menurut SNI nomor 01-42701996, kadar air maksimal untuk susu seral yaitu $3 \%$. Kadar air flakes pisang labu kuning melebihi standar yang ditetapkan SNI dikarenakan dari tepung labu kuning yang digunakan. Kandungan kadar air ini sejalan dengan tekstur yang dihasilkan pada flakes, hal ini dikarenakan kadar protein pada tepung labu kuning rendah sehingga kemampuan mengikat air meningkat, dan mengakibatkan kadar air pada bahan bertambah.

\section{Kadar Serat Kasar}

Serat kasar merupakan bagian dari karbohidrat yang telah dipisahkan denganbahan ekstrak tanpa nitrogen (BETN) yang terutama terdiri dari pati, dengan caraanalisis kimia sederhana (Tillman et al., 1989). Pengujian serat kasar dilakukan untuk mengetahui kandungan serat yan terdapat pada produk flakes pisang labu kuning. Pengujian ini dilakukan pada formulasi konsentrasi tepung pisang $60 \%$, tepung labu kuning $10 \%$, dan tepung terigu $30 \%$ yang merupakan formulasi paling disukai oleh konsumen. Dari hasil pengujian, serat kasar yang didapatkan sebesar $0,745 \%$. Nilai serat kasar ini diatas standar yang ditetapkan pada SNI nomor 01-4270-1996 yaitu sebesar $0,7 \%$. Ha ini disebabkan karena labu kuning memiliki serat yang tinggi, sehingga kandungan serat kasar yang dihasilkan melebihi standar yang ditetapkan.

\section{Kesimpulan}

Dari hasil pengamatan dan pembahasan dapat disimpulkan bahwa formulasi tepung pisang dan tepung labu kuning dalam pembuatan flakes yang paling disukai oleh konsumen adalah dengan perbandingan tepung pisang $60 \%$, tepung labu kuning $10 \%$ dan tepung terigu $30 \%$.

\section{Saran}

1. Perlu dilakukan penelitian lebih lanjut mengenai pembuatan flakes dengan menggunakan metode lain

2. Perlu dilakukan penelitian lebih lanjut mengenai pembuatan flakes dengan menggunakan bahan baku yang memiliki amilopektin tinggi

\section{Daftar Pustaka}

Anggara I., Caesaria C., Anelindha Y., Muhamad A., Rizky S., Hashina L., Trias A., Retna P., Mardiati, Zahryanti D., 2011. Sereal Dengan Bahan Dasar Singkong. Fakultas Farmasi, Universitas Padjajaran. Bandung

A.O.A.C. 1990. Offi cial Method of Analysis. 13th ed. Association of Offi cial Analysis Chemist, Washington, D.C.

BSN. 1996. Susu Sereal SNI 01-4270-1996. Badan Standarisasi Nasional. Jakarta

Cahayaningtyas, F.A., Basito., C. Anam. 2014. Kajian Fisikokimia Dan Sensori Tepung Labu Kuning Curcubita Moschata Durch)Sebagai Substitusi Tepung Terigu Pada Pembuatan Eggroll. Jurnal Teknosains Pangan Vol 3 No. 2 April 2014. Jurusan Teknologi Hasil Pertanian. Universitas Sebelas Maret. Surakarta

Purnamasari, I. K, W. D. R. Putri, 2015. Pengaruh Penambahan Tepung Labu Kuning Dan Natrium Bikarbonat Terhadap Karakteristik Flake Talas. Jurnal Pangan Dan Agroindustri Vol. 3 No 4 P.13751385, September 2015. Jurusan Teknologi Hasil Pertanian, FTP Universitas Brawijaya. Malang

Rahayuning D, 2004. Formulasi Flakes Triple Mixed Ubi Jalar- Kecambah KedelaiWheat 